\title{
The Structure of the Legal Arguments in Islamic Law of War
}

\subsection{Introduction}

The aim of this chapter is to examine how historical identities on the "Islamic" Self and its Other-as discussed in the previous Chapter V in Part II-have informed the creation and application of the universal principles of distinction and proportionality in ILW. Combining the positivist analysis of those rules applicable in armed conflicts — as examined in Chapter I in Part I-with the historical analysis of the context in which the laws of war have evolved over time and in space, can reveal how the structure of the laws of war in theory and in practice have been formulated against those different historical backgrounds. From the period of Revelation and the subsequent Muslim conquests onwards, a shift can be witnessed in the way the jurisdictional scope of ILW has been portrayed. The introduction, by Islamic jurists from the late eighth century, of different abodes, i.e. abode of peace (dar al-Islam) and abode of war (dar al-harb) respectively, avoided the original placatory principles against warfare such as demonstration of patience, persuasion and tolerance as promoted in the primary sources of Islamic law, i.e. the Qur'an and the Sunnah.

From a utilitarian perspective, these legal fictions have served the Islamic leaderships and their empires over the centuries to deal with their enemies at home and abroad. The determination of who can challenge the Islamic authorities and who cannot remains in the hands of the prevailing establishments at a given moment in the history of Islam. Evidently, only the Islamic rulers had the righteous authority to implement Islamic law as opposed to those rebels who were perceived not to understand the correct interpretation to establish the Islamic state and to implement its laws. This same state had to be protected against the Western infidels who have continuously attacked the Islamic community and who have imposed their own Western values since their colonisation of the Muslim lands and minds. In such environment it was justified to use all necessary means to fight internal resistance and external oppression. Hence, the principles of protection could be set aside by such requirements of military necessity. This however, distorted the true application of the sacred texts. 
Although, from a realist perspective, it would be impossible to outlaw war in this world, but from a (religious) humanist perspective, the survival of the human species remains at risk. Respect for all members of humanity-despite their differences-is one of the hallmarks of God's creation. No distinction between peoples whatsoever should be legitimised during peace but in particular during wartime. However, Islamic history has shown that such divisions have primarily served the rulers and the legal authorities, which have benefited from this in order to rule over their divided subjects. The universal message of Islam instead has always favoured the protection of life and human beings above all sorts of divisions introduced by humanity upon itself. Prohibiting the evil and commanding the good within ILW can actually redress the indiscriminate invocation of military necessity to serve the interests of the leaderships at the expense of innocent civilian casualties. The necessity to treat the Other with justice necessarily can lead to a more just world for all members of humanity.

\subsection{Jurisdiction and Distinction}

\subsubsection{Authority in Warfare}

The jurisdictional regimes of ILW are closely connected with the issue of legitimate belligerency and the authority or agency to define such legitimate belligerency. Depending on the nature of the enemies to Islam, i.e. internal or external, the protection granted to them relies on the definition of the conflict and its associated legal regime. Wars of internal resistance to Islam, i.e. rebellion, are regulated by the laws on rebellion (ahkam al-bughat). ${ }^{1}$ Whereas armed conflicts waged between Muslims and non-Muslims, i.e. external jihad, are subject to rules addressing such conflicts of external nature. ${ }^{2}$ The primary sources of Islamic law, however, do not refer to such dichotomous formulation of armed conflicts. Instead, those legal and juristic terms were formulated to meet the needs of the changing context since the Revelation and at the time of the Prophet Muhammad. The political and military context throughout Islam's history has informed the interpretation and application of the initial stipulations in the relevant revealed texts. Rationalising such context in conflicting terms from a political theory perspective permits, within the Islamic world, to set aside the complementary nature of the world as revealed within

1 See Khaled Abou El Fadl, Rebellion and violence in Islamic law (Cambridge University Press 2001).

2 See Chapter I: 1.2.2, 1.3.2, 1.4.2. 
sacred texts. According to Zubaida, "there is a tension between the theoretical sovereignty of the sacred law, and the reality of its co-existence with profane law, and often its confinement in relation to it". ${ }^{3}$ Thus, instrumentalising the context for the creation of legal fictions itself can legitimise the context to live its own reality as fabricated by those legal fictions. In this regard, the dependency on juristic authorities to justify certain political actions recognised the authoritative doctrines as universally applied by the political authorities at a given moment in Islamic history. ${ }^{4}$

For those reasons, the Islamic leadership claimed that obedience to its command was a prerequisite to guarantee the survival of the Islamic faith within a hostile environment in which — at least in the beginning-found support with only a few. In this respect, jihad has been understood by jurists to mean the actual fighting, i.e. qital, against non-Muslims and soon these jurists developed their own doctrine on permanent war with the aggressors of Islam. ${ }^{5}$ Jihad would be the instrument to fulfil God's promise, i.e. the ultimate goal of the Islamic faith. ${ }^{6}$ Throughout many stages of Islamic history, violence was the main instrument to safeguard the Islamic order. Generally, force was the societal norm at the very beginning of and even before the Revelation. Such normalisation and legitimation through the laws of armed conflict reflected the inevitable violent context in which Islam emerged and had to survive. Nonetheless, within this doctrine, until the entire world has been brought under the Islamic religious order, coexistence, which necessarily would accommodate the natural differences amongst peoples across the globe, imposed certain territorial and personal constraints on the use of force. Respectively, ILW had jurisdiction ratione loci (territorial jurisdiction), i.e. in the dar al-Islam and the dar al-harb, as well as jurisdiction ratione personae (personal jurisdiction), i.e. on Muslim believers.

In this respect, the Qur'an does make reference to a world where belief, i.e. iman, and disbelief, i.e. kufr, were naturally and complementarily present in humanity's existence. ${ }^{7}$ The later juristic inferences from this dichotomy within

3 Sami Zubaida, Law and power in the Islamic world (I.B. Tauris 2003), at 79.

4 Wael B. Hallaq, Authority, continuity and change in Islamic law (Cambridge University Press 2001), at 61 and 85 .

5 Bassam Tibi, 'War and peace in Islam', in Sohail H. Hashmi (ed), Islamic political ethics: civil society, pluralism, and conflict (Princeton University Press 2002), at 178.

6 Abdulaziz A. Sachedina, 'The development of jihad in Islamic revelation and history', in James Turner Johnson \& John Kelsay (eds), Cross, cresent, and sword: the justification and limitation of war in Western and Islamic tradition (Greenwood Press 1990), at 36-7.

7 The Qur'an provides many references to the world of belief and disbelief, for example: Q2:108, Q3:167, Q3:176, Q3:177, Q16:106. 
the Qur'an favoured a rather divisive understanding of the world in conflicting terms instead. Therefore, such interpretation necessarily advocated a doctrine of eternal conflict between these two worlds of belief and of disbelief. This legal fiction started to live its own reality. The jurists' perception of the enemies, whether internal (apostates) or external (polytheists, Peoples of the Book), has clearly influenced the development of different jurisdictional regimes within ILW and the different standards of protection provided for them. Of course, the legal classification of an armed conflict was and still is an issue of authority. Regarding the war against non-Muslims, the legal status of such state of war is a matter of recognition in relation to the religious obligation to defend against this aggression as non-Muslims attack and threaten the essence of the Islamic faith (to continue) to exist. ${ }^{8}$ Only the legitimate Islamic authority can go to war against the internal and external enemies of Islam. These authorities would choose those legal regimes which necessarily advanced what they perceived to be the Islamic interest to wage and to win such wars against their enemies. One of the hadiths refers to this authority of Muslim rulers to call for Muslims to fight in the cause of God:

Allah's Apostle said, "There is no Hijra (i.e. migration) (from Mecca to Medina) after the Conquest (of Mecca), but Jihad and good intention remain; and if you are called (by the Muslim ruler) for fighting, go forth immediately." ${ }^{\prime 9}$

Having determined the actual application of the laws of war at a particular time, such juristic contributions have not remained untouched by continuous criticism and resistance of other parties. These opponents were necessarily not involved in the previous process which controlled their thoughts and modes of reasoning. Moreover, the struggle between competing ideologies and their methodologies were usually settled at the expense of the weaker party to this conflict; though, each school of law would like to have seen its own logic/rationalisation to the Revelation to be favoured above other interpretations and applications of ILW..$^{10}$ There was little room for the other parties to the conflict to challenge their (limited) protection as formulated by the juristic authorities. Rebels in particular were considered to disrupt the stability and order within

Majid Khadduri \& Herbert J. Liebesny, Law in the Middle East / Vol. 1, Origin and development of Islamic law (Middle East Institute 1955), at 359. Al-Bukhari, Vol. 4, Book 52, Number 42. (Narrated by Ibn 'Abbas)

10 Norman Calder, Jawid A. Mojaddedi \& Andrew Rippin, Interpretation and jurisprudence in medieval Islam (Ashgate 2007), at Part III (at 981). 
the Islamic community and should be crushed for their ambitions to defy the just and religious leadership of the ummah. Such conflicts within the Islamic community, amounting to exclusion of participation and citizenship within it, ${ }^{11}$ have been criticised by many jurists. Ibn Taymiyya, for example, argued that the invention of ahkam al-bughat, i.e. the laws on rebellion, has been introduced to take away the legitimate belligerent status of rebels fighting the unjust leadership. He found support in the primary sources as no hadith provided for the fighting against rebels but only the fighting against apostates and the Khariji. ${ }^{12}$

The juristic tradition of ILW, however, through its language and modes of interpretation has neutralised the inherent biases and personal preferences it established from its creation onwards. ${ }^{13}$ Such legal formalism conceals its ideological commitment to a divisive worldview by hiding behind the sources of Islamic law. Their interpretations and rationalisations gain legitimacy as they were alleged to be supported by those primary sources. ${ }^{14}$ Apparently, the juristic authorities rather advocated a strict observance to the letter of ILW rather than its spirit. ${ }^{15}$ Vogel continued by stating that the ijtihad can give access to the transcendental knowledge of the divine law, "by offering a broad and final human authority for law, the constitutive compromise supports the horizontal aspiration of a determinate universal divine paradigm for human life. It pays respect to the vertical aspiration of transcendence only by somewhat roundabout technique of delegation, of constructive divine authority."16 Evidently, the rules present within the Qur'an and the Sunnah preceded their man-made implementations as they came straight from God or from the practice of the Prophet Muhammad. However, the rationalists, such as the Mu'tazalis, as opposed to the traditionalists, argued that human reason and agency could extract what the divine justice was about: whether something was good or bad; whereas the traditionalists said that God only could dictate whether some actions were inherently good or bad and believers had to implement such

11 John Kelsay, 'Civil society and government in Islam', in Sohail H. Hashmi (ed), Islamic political ethics: civil society, pluralism, and conflict (Princeton University Press 2002), at 25 .

12 Abou El Fadl, at 62.

13 Lawrence Rosen, The anthropology of justice: law as culture in Islamic society (Cambridge University Press 1989), at 42.

14 Sherman A. Jackson, 'Fiction and formalism: toward a functional analysis of usul al-fiqh', in Bernard G. Weiss (ed), Studies in Islamic legal theory (Brill 2002), at 194.

15 Joseph Schacht, An introduction to Islamic law (Clarendon Press 1965), at 204.

16 Frank E. Vogel, Islamic law and legal system: studies of Saudi Arabia (Brill 2000), at 39. 
divine law. ${ }^{17}$ The latter literalist/traditionalist position, according to Vogel, "lends itself well to the vertical aspiration, since its operation emphasizes the divide between the divine and the human. But it satisfies the horizontal aspiration rather poorly, because it offers no firm, stable, and determinate rules for human life, but only a host of personal guesses at God's law, liable to constant divergences of opinion."18 Despite God's absolute sovereignty as opposed to humanity's relative authority to elucidate the divine commands, both perspectives, however, can be perfectly complementary to each other. According to Hallaq, "for revelation cannot be understood without the intervention of human reason, just as human reason cannot, without the aid of revelation, comprehend the divine intention". 19

For more than three centuries after the Revelation, the tension between juristic and political authorities caused major divisions and gaps which were exploited by leaders on both sides to advance their authority at the expense of the other, both in relation to the Muslim population as well as to the nonMuslim inhabitants and foreigners. It was the Abbasid dynasty which reconciled the juristic and political prerogatives within the Islamic state ${ }^{20}$ and it were the jurists who were the guardians of Islamic law. ${ }^{21}$ It is this technical legal language as created and used by juristic authorities that served as a primary instrument for jurists to assert and legitimise their power over the normative arguments within ILW. With respect to the conduct of warfare, these arguments had to be guided by the jurists' preferences. They also determined how and who could challenge their authority both doctrinally as well as on the battlefield. ${ }^{22}$ Jurists did not only claim interpretative authority over the revealed texts, they also set up a sophisticated methodology to access the text from the human context. From their professional juristic guilds they had recourse to abrogation, i.e. naskh, which repeals one legal provision by another one. ${ }^{23}$ This legal technique, as applied by classical jurists in relation to the

17 Norman Anderson, Islamic law in the modern world (New York University Press 1959), at 9 .

18 Vogel, at 39.

19 Wael B. Hallaq, A history of Islamic legal theories: an introduction to Sunni usul al-fiqh (Cambridge University Press 1999), at 225.

20 David F. Forte, Studies in Islamic law: classical and contemporary application (Austin \& Winfield 1999), at 11-25.

21 Colin Imber, Ebu's-su'ud: the Islamic legal tradition (Edinburgh University Press 1997), at 65 .

22 Abou El Fadl, at 106 and 321.

23 Aqil Ahmad \& Iqbal Ali Khan, Text book of Mohammedan law (Central Law Agency 2004), at 20. 
different verses on warfare, had mostly ignored the principles of tolerance and peace, which the primary sources of Islamic law stand for and whose message would be convincing enough to persuade non-Muslims in their relations with the Muslims. ${ }^{24}$ Hence, the so-called "sword verses" were favoured at the expense of the "peace" ones. ${ }^{25}$

Such attitudes necessarily promote even greater tension between the warring parties and their causes to go to war and in particular regarding their respect of the laws of war during the actual hostilities. One party or the other will always be more excluded than the other; in spite of the reciprocal character of warfare, such marginalisation can lead to even more violations of the laws of war knowing that the unprivileged legal position of such party to the conflict creates a gap within the law between the legitimate warring party and the disadvantaged one. Such asymmetrical situation and sharp distinction in ILW reinforces the asymmetrical conditions on the battlefield; while the primary sources of ILW would have been put in place to avoid such unequal treatment of belligerency and to provide protection during warfare in the first place. Nonetheless, also as a matter of reciprocity, treating the enemy well would lead to the same courtesy on behalf of the opponent. In addition, the dehumanisation of the Other in the conflict justified not to take or apply the principles of distinction and proportionality strictly. If the ummah had to be preserved and protected for the coming generation of Muslims, a humanitarian cost could not be avoided. In this respect, wars would be the necessary means to achieve this goal and to implement God's command to serve humanity in this manner. That is why many Muslim rulers over time have claimed that wars were a necessary evil to establish ultimate peace on earth. The second caliph Umar Ibn Al-Kattab, however, was convinced that Islam would prevail not because of its force but instead because of the respect it imposes for the values it is sharing with other peoples. ${ }^{26}$ Again, reciprocity, as a matter of natural law, would bring the warring parties to act justly with each other both for the good and the bad. For example the Qur'an states the following:

24 M. Raquibuz Zaman, 'Islamic perspectives on territorial boundaries and autonomy', in Sohail H. Hashmi (ed), Islamic political ethics: civil society, pluralism, and conflict (Princeton University Press 2002), at 92.

25 See Chapter I, 1.2.1, Footnotes 13 and 15.

26 Sheikh Wahbeh al-Zuhili, 'Islam and international law', (2005) 87 International Review of the Red Cross, 269, at 274. 
Allah commands justice, the doing of good, and liberality to kith and kin, and He forbids all shameful deeds, and injustice and rebellion: $\mathrm{He}$ instructs you, that ye may receive admonition. (Q16:90)

All empires having emerged ever since the creation of the major schools of Islamic law within Sunni Islam, remained faithful to the doctrines framed by that school as it limited and justified their actions and authority by those doctrines and methodologies. ${ }^{27}$ Any further development by juristic authorities working for the political authorities within those empires attributed their interpretations and findings to one or the other school of thought. ${ }^{28}$ Such doctrinal and juristic authority, however, as opposed to the authority residing in the primary sources of Islamic law, has only a relative meaning which remains subject to change and mediation. ${ }^{29}$ Within such environment of legal pluralism, changing contexts over time would give rise to other interpretations of the laws of war. ${ }^{30}$ This doctrinal diversity has been severely put at risk by the Western colonial presence in the Muslim lands where the juristic conscience was detached from its doctrinal foundations and replaced by a positivist Western classification and codification of the legal system. ${ }^{31}$ This of course caused major tensions between traditionalists and modernists respectively wanting to protect/re-Islamise ${ }^{32}$ the past legal pluralism and advance toward a more predictable nature of a uniform rationalised doctrine on the sources of law of the country in question. Hallaq mitigated and found that this latest trend had similar evolutions already from the early beginning of Islam's history:

27 Bernard G. Weiss, 'The madhhab in Islamic legal theory', in P.J. Bearman, Rudolph Peters \& Frank E. Vogel (eds), The Islamic school of law: evolution, devolution, and progress (Harvard University Press 2005), at 1-2; Gudrun Krämer \& Sabine Schmidtke, 'Introduction: religious authority and religious authorities in Muslim societies: a critical overview', in Gudrun Krämer \& Sabine Schmidtke (eds), Speaking for Islam: religious authorities in Muslim societies (Brill 2006), at 5 .

28 Wael B. Hallaq, 'Takhrij and the construction of juristic authority', in Bernard G. Weiss (ed), Studies in Islamic legal theory (Brill 2002), at 333 .

29 Weiss, in, at 4.

30 Ihsan Yilmaz, 'Inter-madhhab surfing, neo-ijtihad, and faith-based movement leader', in Peri J. Bearman, Rudolph Peters \& Frank E. Vogel (eds), see id., at 192.

31 Yadh Ben Achour, Politique, religion et droit dans le monde arabe (Cérès productions 1992), at 7 .

32 Bernard Botiveau, Loi islamique et droit dans les sociétés arabes: mutations des systèmes juridiques du Moyen-Orient (Karthala 1993), at 277. 
The search for a legal identity in twentieth-century Islam and the crises that are associated with reformulating both a legal theory and a general concept of law represent the latest historical stage in which humanistic and positivist tendencies have collided with the imperatives of revelation. True, this collision is unprecedented in the profound impact and the havoc it wreaked upon the intellectual and structural make-up of the traditional Islamic legal systems. But the tension between reason and revelation-that is, between human considerations of man's own welfare in this life, on the one hand, and divine intervention and decree, on the other-has been consistently present since Muhammad migrated to Medina. $^{33}$

\subsubsection{OnJurisdiction}

Besides the divisive policies of the juristic and political authorities, their presence proved to be complementary and crucial in the endeavours to administer the growing Islamic empires ever since the death of the Prophet. A united Islamic community was the ultimate prerequisite to survive in a hostile environment and to safeguard its expansion. Most Muslim emigrants were Arabs having left their homeland to serve their religion in the new Muslim lands in the Middle East. ${ }^{34}$ Other non-religious motives had also pushed these first settlers of the garrison cities out of the Arabian Peninsula, such as hunger, poverty, and demographic expansion. ${ }^{35}$ The early Umayyad dynasty did favour the position of Arab tribes above non-Arab peoples and the departure from the egalitarian norms which the sacred texts provided. ${ }^{36}$ Since the end of the Umayyad dynasty where primarily Arab interests had been served, the tribal differences among Muslims blurred and an undivided Islamic community established itself in juxtaposition to the other great empires at that time. ${ }^{37}$ This unity found its political representation through, in the first place the Caliphate, and later onwards under the Ottomans, through the sultanate. Especially from the Abbasid dynasty, transcending the Arab privileges of the previous leaderships

\footnotetext{
33 Hallaq, A history of Islamic legal theories: an introduction to Sunni usul al-fiqh, at 255 .

34 Patricia Crone, 'The early Islamic world', in Kurt Raaflaub \& Nathan Rosenstein (eds), War and society in the ancient and medieval worlds: Asia, the Mediterranean, Europe, and Mesoamerica (Harvard University Press 1999), at 312.

35 Edward Hotaling, Islam without illusions: its past, its present, and its challenges for the future (Syracuse University Press 2003), at 100.

36 Wael B. Hallaq, The origins and evolution of Islamic law (Cambridge University Press 2006), at 180 .

37 Gerasimos P. Makris, Islam in the Middle East: a living tradition (Blackwell Publishing 2007), at 45 .
} 
restored the initial doctrine of Islam having rather a communitarian aspiration to assemble all peoples through its faith. ${ }^{38}$ Therefore, the establishment of an Islamic community was necessary to clearly differentiate the outside chaotic world of lawlessness from the Islamic world where the Islamic community and its leaders could implement the divine laws peacefully. 39

However, only some interpretations of the Islamic laws have been authoritative enough to claim their universality. ${ }^{40}$ Strictly speaking, the universal nature of Islamic law only has a personal character and binds all Muslims, including the leaderships of those territories under Muslim sovereignty. ${ }^{41}$ Such Islamic conscience creates duties and rights for Muslims, not only vertically between God and the Muslims as revealed within the sacred texts but also in its horizontal application among the Muslims themselves. ${ }^{42}$ As an ideal unity ${ }^{43}$ represented in the oneness of God and its creation, the harmony reached through the ummah's consciousness integrated people's conscience and the textual conscience. In terms of salvation, the nurturing force of the ummah had to spread so it could transcend the natural differences that have been exploited by humanity. ${ }^{44}$ Nevertheless, the intention to assemble peoples under the same Islamic religion, changed into disunity whenever the invitation to embrace the truth of Islam has been rejected by other religions. ${ }^{45}$ Within such world order, it was necessary to profile the Islamic religion as distinctive from other faiths, ${ }^{46}$ as the other faiths did also profile themselves as being distinctive from Islam.

38 Edward Mortimer, Faith and power: the politics of Islam (Faber and Faber 1982), at 40.

39 Muhammad Mumtaz Ali, The concepts of Islamic Ummah \& Shariah (Pelanduk Publications 1992), at 4.

40 Fred Halliday, Islam and the myth of confrontation: religion and politics in the Middle East (I.B. Tauris 2003), at 115 .

41 Aharon Layish, Islamic law in the contemporary Middle East (Centre of Near \& Middle Eastern Studies, School of Oriental and African Studies, University of London 1989), at 1.

42 Mahmoud M. Ayoub, Islam: faith and history (Oneworld 2004), at 220.

43 W. Montgomery Watt, Islam and the integration of society (Routledge \& Kegan Paul 1966), at 90 .

44 Frederick M. Denny, 'The problem of salvation in the Quran: key terms and concepts', in Arnold H. Green (ed), In quest of an Islamic humanism: Arabic and Islamic studies in memory of Mohamed al-Nowaihi (The American University in Cairo Press 1986), at 207.

45 Peter Antes, 'Relations with the unbelievers in Islamic theology', in Annemarie Schimmel \& Abdoldjavad Falaturi (eds), We believe in one God: the experience of God in Christianity and Islam (Burns \& Oates 1979), at 103.

46 W. Montgomery Watt, Islamic revelation in the modern world (Edinburgh University Press 1969), at 99-100. 
In this respect, the Qur'an is particularly illustrative of this privileged belonging as well as the rights and responsibilities to preserve the ummah:

And hold fast, all together, by the rope which Allah (stretches out for you), and be not divided among yourselves; and remember with gratitude Allah's favour on you; for ye were enemies and He joined your hearts in love, so that by His Grace, ye became brethren; and ye were on the brink of the pit of Fire, and He saved you from it. Thus doth Allah make His Signs clear to you: that ye may be guided. (Q3:103)

Be not like those who are divided amongst themselves and fall into disputations after receiving Clear Signs: for them is a dreadful penalty. (Q3:105)

Ye are the best of peoples, evolved for mankind, enjoining what is right, forbidding what is wrong, and believing in Allah. If only the People of the Book had faith, it were best for them: among them are some who have faith, but most of them are perverted transgressors. (Q3:110)

This Islamic conscience defined any opposition against it as part of a strategy to destroy their Islamic community both from within as from outside. This conscience was particularly raised whenever conflicts occurred and where the Islamic leadership and authority had been challenged. In this respect, from its early establishment, non-Muslims, such as the Jews and the Byzantine Christians feared the Islamic community and launched first attacks against their new neighbours. As a matter of self-defence, Muslims took those necessary measures against the aggressors. Also from the Middle Ages, Western crusades $^{47}$ in and the later Western colonisation of the Muslim lands from the nineteenth century onwards, created further tensions between the Muslims and the West. ${ }^{48}$ The frustration felt ever since by Muslims which were divided by the West's intervention and occupation in their territories continued to manifest itself through the establishment of secular nation states. ${ }^{49}$ Those modernisation projects were considered as other attempts to continue to divide both

47 Françoise Micheau, 'Les croisades vue par les historiens arabes d'hier et d'aujourd'hui', in Françoise Micheau (ed), Les relations des pays d'islam avec le monde latin: du milieu du $\mathrm{X}^{\mathrm{e}}$ siècle au milieu du XIII ${ }^{\mathrm{e}}$ siècle (Editions Jacques Marseille 200o), at 67.

48 John L. Esposito, The Islamic threat: myth or reality? (Oxford University Press 1999), at 17.

49 John L. Esposito, Unholy war: terror in the name of Islam (Oxford University Press 2002), at 40 . 
the territory and identity of Muslim peoples. ${ }^{50}$ Although the sacred texts have always acknowledged the natural division between humanity as a whole and the privileged community of Muslims, the territorial fiction as produced by the early Islamic jurists continued to serve its purpose to defend Islam against any aggression or even to expand Islam according to today's Islamic extremists. ${ }^{51}$ Instead, the complementary reality of God's creation, ${ }^{52}$ i.e. a world of belief and a world of disbelief, has been translated into a divisive political and legal ideology as coined during the Islamic conquests and thereby projected the Muslim world to be at war with the non-Muslims. ${ }^{53}$ Although these non-Muslims necessarily have not found the complete truth which God revealed to the Prophet or have not come under the Islamic sovereignty yet, ${ }^{54}$ the Qur'an remains strict in regulating the waging of jihad against them. As part of the higher objectives of the Shari'a, i.e. maqasid al-Shariah, namely to command the good and forbid the evil, Muslims are encouraged not to attack first:

Fight in the cause of Allah those who fight you, but do not transgress limits; for Allah loveth not transgressors. (Q2:19o)

To those against whom war is made, permission is given (to fight), because they are wronged;- - and verily, Allah is most powerful for their aid. (Q22:39)

According to that divisive doctrine, the dar al-harb where non-Muslims reside and where the Islamic authority does not yet prevail, war would be a necessary means to protect the Islamic conscience from aggression. However, war could never be a moral end in itself. ${ }^{55}$ Moreover, the Islamic faith has always acknowledged the complementarity of the tension between war and peace in the material world and more importantly also the obligation to struggle for

50 David Zeidan, The resurgence of religion: a comparative study of selected themes in Christian and Islamic fundamentalist discourses (Brill 2003), at 256.

$5^{1}$ James P. Piscatori, Islam in a world of nation-states (Cambridge University Press 1991), at 46 .

52 Hamadi Redissi \& Jan-Erik Lane, 'Does Islam provide a theory of violence?' in Amélie Blom, Laetitia Bucaille \& Luis Martinez (eds), The enigma of Islamist violence (Hurst \& Company 2007), at 27-8.

53 Bassam Tibi, 'War and peace in Islam', in Andrew G. Bostom (ed), The legacy of jihad: Islamic holy war and the fate of non-Muslims (Prometheus Books 2005), at 328.

54 Riaz Hassan, Inside Muslim minds (Melbourne University Press 2008), at 110.

55 Khaled Abou El Fadl, The great theft: wrestling Islam from the extremists (HarperCollins Publishers 2005), at 223. 
a peaceful world on the spiritual level, i.e. the inner jihad. ${ }^{56}$ If external jihad against non-Muslims was supposed to open all of humanity to Islam, ${ }^{57}$ then how would the Qur'anic prohibition of compulsion in religion (Q2:256) continue to be respected? Also since the decolonisation of the Muslim lands, the fight led by those Islamic extremists against the secularisation of the Muslim states is considered to be waged against Muslim leaders who are viewed as stooges and foreigners corrupted by Western governments. ${ }^{58}$ Consequently, ILW regulating armed conflicts against non-Muslims also apply to them; though, technically speaking, these political establishments are still Muslims under Islamic law. Nonetheless, from the perspective of natural law, the principles of distinction and proportionality have to be respected by all warring parties to the conflict regardless whether they are Muslims or not. The same thing can be said of the global jihad as a technique to externalise their allegedly internal enemies of Islam within the Muslim states in order to avoid the protection given to Muslims for wars conducted among Muslims. ${ }^{59}$ In spite of the fragmentation of the Islamic world into nation states, the liberation of the several national ummahs from Western imperialism as already witnessed in the early encounters with the Byzantine Empire, ${ }^{60}$ would find a transnational support among all ummahs sharing the same experiences of oppression and corruption. ${ }^{61}$ Undeniably, the recourse to the doctrine of dar al-Islam and dar al-harb has served to legitimise such actions against the perceived infidels. ${ }^{62}$ This Other, according to Sharma, "would be a constant ontological irritant to

$5^{6}$ Mary R. Habeck, Knowing the enemy: jihadist ideology and the war on terror (Yale University Press 2006), at 53 .

57 Bassam Tibi, The challenge of fundamentalism: political Islam and the new world disorder (University of California Press 1998), at 54.

$5^{8}$ Thomas Scheffler, 'West-Eastern cultures of fear: violence and terrorism in Islam', in Kai Hafez \& Mary Ann Kenny (eds), The Islamic world and the West: an introduction to political cultures and international relations (Brill 2000), at 77; Gilles Kepel, The war for Muslim minds: Islam and the West (The Belknap Press of Harvard University Press 2004), at 74 .

59 Fawaz A. Gerges, The far enemy: why jihad went global (Cambridge University Press 2005), at 160 .

6o Anthony Pagden, Worlds at war: the 2500-year struggle between East and West (Oxford University Press 2008), at 202.

61 Stephen Vertigans, Militant Islam: a sociology of characteristics, causes and consequences (Routledge 2009), at 71-5.

62 Andrew Wheatcroft, Infidels: the conflict between Christendom and Islam, 638-2002 (Viking 2003), at 323 . 
the faithful". ${ }^{63}$ Within this purview, the Islamic conscience could again prevail against the Western globalizing and materialistic values; ${ }^{64}$ in spite of the ethnic lines along which Muslims have started to identify themselves with, as seen in the conflicts in Afghanistan, Pakistan and the former Yugoslavia. ${ }^{65}$

With respect to the later modern internal armed conflicts among Muslims, it appears that the fragmentation introduced by the West through its colonisation of the Muslim lands has left a deep division along ethnic and racial lines, beyond the common religious identity of Muslims; ${ }^{66}$ something which Muslims have already witnessed before the Umayyad dynasty whose leadership initially has been assumed by Arabs. Only later in the political history of Islam, has the leadership been shared by other peoples within the Islamic world, such as the Mughals, Persians and Turks. The real division, however, among Muslims throughout their history has rather been of a social nature where juristic, political and military establishments were dictating ordinary people. ${ }^{67}$ The former needed to make sure that all Muslims abide by their extrapolation of rules which were derived from the sacred texts. Therefore, obedience was crucial to capitalise the universal message of Islam. ${ }^{68}$ Any resistance from within the Islamic community against the unity of the Islamic state had to be suppressed both physically and psychologically. Under the doctrine of predestination, the Muslim masses could be controlled as the social hierarchy in which they found themselves had been determined by God. ${ }^{69}$ Although there exists social inequality, a greater bound of solidarity would unite the Muslims and bring social change in this world, for example through zakat. ${ }^{70}$ Despite these common aspirations, Islamic leaderships throughout their history have suffered from opposition and inversely have accused and oppressed

63 Shashi S. Sharma, Caliphs and sultans: religious ideology and political praxis (Rupa 2004), at 39 .

64 Alan G. Jamieson, Faith and sword: a short history of Christian-Muslim conflict (Reaktion Books 2006), at 208.

65 Tibi, The challenge of fundamentalism: political Islam and the new world disorder, at 131.

66 Zubair Murshed, 'Power and identity in the discourse of jihad', (2003) 7 Gender Technology and Development, 399, at 412.

67 Patricia Crone, Medieval Islamic political thought (Edinburgh University Press 2004), at 355 .

68 Tilman Nagel \& Thomas Thornton, The history of Islamic theology: from Muhammad to the present (Markus Wiener 2000), at 35 and 57.

69 Ignáz Goldziher, Bernard Lewis, Andras Hamori \& Ruth Hamori, Introduction to Islamic theology and law (Princeton University Press 1981), at 84.

70 Khurram Murad \& Abdur Rashid Siddiqui, Inter-personal relations: an Islamic perspective (Islamic Foundation 2005), at 2. 
violently their opponents under the guise of the defence of their own vision of Islamic values. ${ }^{71}$ Technically, ILW remained applicable for those armed conflicts among Muslims. However, based on the claimed sovereign legitimacy of the Islamic leadership, it could determine the rebellious Other as brigands, i.e. muharibun, and consequently circumvent the protection which ILW guaranteed for those Muslims fighting its rule.

And fight them on until there is no more tumult or oppression, and there prevail justice and faith in Allah. But if they cease, let there be no hostility except to those who practise oppression. (Q2:193)

Allah's Apostle said, "A Muslim is a brother of another Muslim, so he should not oppress him, nor should he hand him over to an oppressor. Whoever fulfilled the needs of his brother, Allah will fulfill his needs; whoever brought his (Muslim) brother out of a discomfort, Allah will bring him out of the discomforts of the Day of Resurrection, and whoever screened a Muslim, Allah will screen him on the Day of Resurrection."72

The Prophet said, "It is obligatory for one to listen to and obey (the ruler's orders) unless these orders involve one disobedience (to Allah); but if an act of disobedience (to Allah) is imposed, he should not listen to or obey it."73

In today's conflicts across the Islamic world in general and the Middle East in particular, one witnesses strong oppositions between the central authorities and local constituencies. The brutality of the autocratic regimes suppresses the voices of its political and religious opponents. Ethnic and racial divisions, as once introduced by Western colonialism, have even further highlighted the polarisation between different groups in those societies. In Afghanistan and Pakistan, rebellious forces challenge the Western interventionist forces as well as the central governments because of their corruption and lack of piety or even apostacy. Such opposition has been violently crushed as for example in 2009 in the Swat valley of Pakistan. The transnational nature of the conflict in South Asia makes its even more difficult to have recourse to IHL and ILW instead offers an unique opportunity to regulate the conduct of hostilities not

\footnotetext{
71 Javaid Rehman, Islamic state practices, international law and the threat from terrorism: a critique of the "clash of civilizations" in the new world order (Hart 2005), at 59.

72 Al-Bukhari, Vol. 3, Book 43, Number 622. (Narrated by 'Abdullah bin Umar)

73 Al-Bukhari, Vol. 4, Book 52, Number 203. (Narrated by Ibn 'Umar)
} 
on the basis of territoriality, i.e. international and non-international armed conflicts, but rather on the basis of personal jurisdiction, i.e. war between Muslim believers and non-Muslims. Also the 2011 Arab Spring exposed the unsustainability of dictatorial rule upon the general populace. Although their existence relied in part on the international support especially from Western countries, popular resistance has questioned the legitimacy of its rule. As a response, those voices have been undermined and denounced as terrorist attempts to destabilise the respective countries and their regimes, such as in Libya and Syria. The continued violence in the Horn of Africa equally shows proof of the conflict between rebellions and central authorities in Somalia. All Muslims are bound by Islamic law and certain protective measures are imposed during warfare. However, the qualification of such conflict largely depends on the strongest party to the conflict, namely to recognise the cause of its opponents and afford them the necessary protection under the jurisdictional regimes of the laws of war.

\subsubsection{On Distinction}

All human beings are equal before God and no distinction in treatment during warfare can be made ${ }^{74}$ except between combatants, i.e. those participating in the armed hostilities, and non-combatants. ${ }^{75}$ Both in external and internal jihad, this communitarian and naturalist principle of distinction between combatants and civilians has been sanctioned by several hadiths ${ }^{76}$ but can be set aside whenever dictated by military necessity. This is the case when the enemy violates this same principle; then Islamic fighters can as a matter of reciprocity violate likewise yet proportionate to the violation by the enemy. This sovereignty argument of necessity has also been guided by ideological motivations and classifications of the enemy. The Other necessarily has threatened the Islamic community from outside or even from within. Most asymmetrical conflicts, such as the Israeli-Palestinian one, translate the frustration of the oppressed peoples both internally and externally and justify the violation of principles of protection such as distinction/discrimination by shifting the responsibility of collateral damage of innocent civilians upon

74 M. Kheir Ereksoussi, 'Le Coran et les conventions humanitaires', (1960) 503 International Review of the Red Cross, 641, at 644 .

75 James J. Busuttil, ' "Slay them wherever you find them”: humanitarian law in Islam', (1991) 30 Revue de Droit Militaire et de Droit de la Guerre, 111, at 122.

76 For example: Al-Bukhari, Vol. 4, Book 52, Number 257. (Narrated by 'Abdullah) and Al-Bukhari, Vol. 4, Book 52, Number 28o. (Narrated by Abu Sa'id Al-Khudri) 
the enemy's fault to have involved its populace within such conflict. ${ }^{77}$ Others, however, like the Persian (Isma'ili) Nizaris, launched discriminatory targetted killings or assassinations against their enemies, consequently avoiding a lot of bloodshed. ${ }^{78}$ The Qur'an also prescribes this very issue where the Muslims can punish the enemy who has been aggressive against the Islamic community but within the limits of proportionality.

The prohibited month for the prohibited month,- - and so for all things prohibited,- - there is the law of equality. If then any one transgresses the prohibition against you, transgress ye likewise against him. But fear Allah, and know that Allah is with those who restrain themselves. (Q2:194)

However, as part of commanding the good and forbidding the evil, Muslim fighters should spare those who are not participating in the armed conflict and use only force against other combatants. ${ }^{79}$ Performing this main objective by adhering to the principle of distinction during external and internal jihad, the enemy necessarily can be persuaded of the communitarian and naturalist values of Islam to honour life and of the moral conduct of Muslim fighters who are defending the Islamic community against aggressors from outside and inside the ummah. On the other hand, the Revelation is not blind to the threats posed against the Islamic faith and consequently accepts belligerent reprisals against the enemies of Islam as a just cause ${ }^{80}$ Because jihad is, ideally, aimed at opening the whole of humanity to the goodness of Islam, the Qur'an necessarily recognises reciprocity and apparently expects the Other, the enemy of Islam, as a matter of natural law recognised by all peoples and civilisations of the world, to respect ILW although, in sensu stricto, Islamic law is only applicable to Muslims. This is also the case where the central Islamic authorities considered their Muslim enemies inside the ummah to be no longer Muslims and to have fallen outside the scope of protection of ILW. Nonetheless, in view of demonstrating tolerance and patience towards the external and internal Other

77 John Kelsay, 'Islam and the distinction between combatants and noncombatants', in James Turner Johnson \& John Kelsay (eds), Cross, crescent, and sword: the justification and limitation of war in Western and Islamic tradition (Greenwood Press 1990), at 208-9.

78 Marshall Goodwin Simms Hodgson, The venture of Islam: conscience and history in a world civilization (The University of Chicago Press 1974), at 137.

79 Seyyed Hossein Nasr, 'Islam and the question of violence', in Aftab Ahmad Malik (ed), With God on our side: politics and theology of the war on terrorism (Amal Press 2005), at 274-75.

8o Maimul Ahsan Khan, Human rights in the Muslim world: fundamentalism, constitutionalism, and international politics (Carolina Academic Press 2003), at 133. 
which has become externalised, the Qur'an calls for a balanced and proportional attitude in warfare instead of justifying dehumanising discourses that curtail those objectives.

Invite (all) to the Way of thy Lord with wisdom and beautiful preaching; and argue with them in ways that are best and most gracious: for thy Lord knoweth best, who have strayed from His Path, and who receive guidance. (Q16:125)

And if ye do catch them out, catch them out no worse than they catch you out: But if ye show patience, that is indeed the best (course) for those who are patient. (Q16:126)

Some hadiths as well as recorded orders of the early Caliphs explicitly call for the respect of the principle of distinction, for example:

During some of the Ghazawat of the Prophet a woman was found killed. Allah's Apostle disapproved the killing of women and children. ${ }^{81}$

Do not kill a minor child or an old man of advanced age or a woman. ${ }^{82}$

Do not kill an old man or a woman or a minor..$^{83}$

\subsection{Necessity and Proportionality}

\subsubsection{Actions of Warfare}

From the analysis of the application of the different jurisdictional regimes of ILW which regulate the conduct of armed hostilities in the external and internal jihad, it is clear that throughout the history of Islam the authority to choose and to call for the observation of these legal regimes which provide the necessary protection, in particular towards non-combatants, has been subject to the classification and dehumanisation of the enemy to Islam. Given the continuous threats the Islamic empires faced from outside and within the Islamic community, violence became normalised and the doctrines on the laws of war

\footnotetext{
81 Al-Bukhari, Vol. 4, Book 52, Number 257. (Narrated by 'Abdullah)

82 Abu Bakr cited in Muhammad Hamidullah, Muslim conduct of state (Sh. Muhammed Ashraf 1961), at 307 .

83 Umar cited in Id., at 309 .
} 
reflected the divisions which the practice has created. Although this division of the world into the abode of Islam and abode of war, as introduced by the jurists under the Abbasid dynasty, had no textual support whatsoever within the sacred texts, it started to live its own reality serving the leadership at a given moment to divide and rule over peoples across both abodes. ${ }^{84}$ At the discretion of the Islamic leadership, the conflicts against their opponents both internally and externally could be classified as threats against the religion and trigger the application of the laws of war regulating respectively the internal and external jihad.

On the one hand, given the necessities of warfare and as a matter of reciprocity, the principle of distinction is difficult to be observed in particular when the Other has violated this same principle of discrimination against the Muslim population. In fact, the Qur'an permits reciprocity in warfare. ${ }^{85} \mathrm{On}$ the other hand, Islam, in order to convince non-Muslims or those who have renounced Islam such as the apostates, wants to promote the good and forbid the evil. Such Islamic conscience would necessarily attract many new (and old) members to follow the straight path (again). For the sake of demonstrating this balance which Islam stands for, during armed conflicts, Islam allows the lifting of a prohibition to attack non-combatants as a matter of revenge but would limit its fighters in their reprisals. ${ }^{86}$ It is against this background that it becomes clear that Islam restrains fighting and wants to avoid a vicious circle of violence against its enemies, especially while it is being faced with the challenges to protect its community of followers. Though there seems to be a conflict between the protection of the ummah and the avoidance of endless reprisals, the task, however, of Islam is to approximate the ultimate objective to command the good and to forbid the evil. In this respect, violence necessarily would not be the ultimate means to achieve this end or to settle this tension at the expense of a balanced approach during armed hostilities.

In addition, as with the actual application of the rules of the different jurisdictional regimes, the proportionate or balanced conduct of warfare necessarily will be affected by the image of the "Islamic" Self and its neglected Other; even if this Other violates ILW and hence calls for retaliation on behalf of the Muslim fighters. If in the first place the fictional division of the world in conflicting terms already departs from the complementary reality of the world of belief and disbelief as revealed in the Qur'an, then such legal justification outside the sacred text would give voice again to the interests of the rulers

\footnotetext{
84 Marcel A. Boisard, L'humanisme de l'islam (Albin Michel 1979), at 214.

85 See for example Q2:191.

86 See Q2:19o.
} 
to divide and dominate their Others. In this regard, under the guise of a continuously changing public interest, i.e. maslaha, and on the basis of military necessity, prevalence can be given to the Islamic cause which is alleged to be under threat by the enemy. Consequently, disproportionate violence has always taken place throughout the history of Islam; from the Arab conquests, the Mongol invasions, the World Wars until the present Global War on Terror and Arab Spring. ${ }^{87}$ And obedience to the (Islamic) leadership would prevent any criticism to challenge such indiscriminate and disproportionate actions in warfare.

\subsubsection{On Necessity}

In case of emergency, the prohibition of disproportionate actions against the enemy can be overridden, i.e. al-darura tubih al-mahzurat. ${ }^{88}$ Darura, i.e. necessity, has been developed, based on Qur'anic principles, ${ }^{89}$ by jurists to allow for certain actions which are normally prohibited..$^{90}$ When this urgent and public need, such as the defence of Muslims, has not been met, then the ummah might even face worse consequences instead. ${ }^{91}$ Military necessity is usually invoked to protect the public good of the ummah, i.e. maslaha, and to justify reprisals in case of violations of the laws of war by the enemy as a matter of reciprocity. ${ }^{92}$ In warfare, the conditions under which such military necessity is allowed is unclear and subject to discussion. In this discussion, from the doctrinal point of view, it is possible that a changed custom itself can set aside the prevailing authoritative doctrines. ${ }^{93}$ The particularity of a custom as developed by the diverse communities within the ummah can advance a contextualised answer to the universalising opinions of the central juristic authorities. From the practical point of view, on the battlefield, the asymmetrical position of the Muslim fighters can push them into having recourse to less conventional

87 Ye'or Bat, Islam and dhimmitude: where civilizations collide (Fairleigh Dickinson University Press 2002), at 48-9.

88 Tibi, 'War and peace in Islam', in, at 331.

89 See for example Q2:173.

9o Ihsan Yilmaz, 'Inter-madhhab surfing, neo-ijtihad, and faith-based movement leader', in Peri J. Bearman, Rudolph Peters \& Frank E. Vogel (eds), The Islamic school of law: evolution, devolution, and progress (Harvard University Press 2005), at 193.

91 Mohammad Muslehuddin, Islamic jurisprudence and the rule of necessity and need (Islamic Research Institute 1975), at 62.

92 Sohail H. Hashmi, 'Saving and taking life in war: three modern Muslim views', in Jonathan E. Brockopp (ed), Islamic ethics of life: abortion, war, and euthanasia (University of South Carolina Press 2003), at 146-47.

Hallaq, Authority, continuity and change in Islamic law, at 231. 
means and methods of warfare such as indiscriminate weaponry or terrorist actions. The use of fire weapons in urban combat in the early Islamic military campaigns, is an illustration thereof: ${ }^{94}$ despite its prohibition based on the belief that only God has the prerogative to punish with fire, as indicated in the following hadith:

Allah's Apostle sent us in a mission (i.e. an army-unit) and said, "If you find so-and-so and so-and-so, burn both of them with fire." When we intended to depart, Allah's Apostle said, "I have ordered you to burn soand-so and so-and-so, and it is none but Allah Who punishes with fire, so, if you find them, kill them." 95

Moreover, the symbolic value of such warfare-deemed to be necessary for the Muslims to challenge and to defend the enemy-inflicts fear upon this aggressive Other and rallies the support of all members of the Islamic community for its religious cause. In particular, Islamic extremists have exploited this dichotomy between the Self and the Other ${ }^{96}$ and attracted many foreign fighters to confront Western intervention in their peripheries, such as in Afghanistan, Iraq and the former Yugoslavia. ${ }^{97}$ For example, according to al-Zarqawi, one of the former leaders of al-Qaeda, those infidels who are unwilling to conclude peace with the Muslims can not be protected against targeting unless for the most vulnerable such as children and women. ${ }^{98}$ Likewise for armed conflicts among Muslims, if the enemy violates the commands of God, then, as a matter of belligerent reprisal, Muslim fighters have to ensure that their Muslim enemies comply again with God's commands. ${ }^{99}$ Within such internal or even external jihad it is possible that innocent believers get killed by other Muslims. For example when Muslim captives used as human shields have been killed. ${ }^{100}$ Their death, as part of the doctrine of predestination, would be justified to

94 Hugh Kennedy, The armies of the caliphs: military and society in the early Islamic state (Routledge 2005), at 177 .

95 Al-Buhkari, Vol. 4, Book 52, Number 259. (Narrated by Abu Huraira)

96 Amélie Blom, Laetitia Bucaille \& Luis Martinez, 'Introduction: imaginaires of Islamist violence', in Amélie Blom, Laetitia Bucaille \& Luis Martinez (eds), The enigma of Islamist violence (Hurst \& Company 2007), at 16-17.

97 Jean-Pierre Filiu, Les frontières du jihad (Fayard 2006), at 283.

98 Devin R. Springer, James L. Regens \& David N. Edger, Islamic radicalism and global jihad (Georgetown University Press 2009), at 176.

99 Q49:9.

100 Mawil Izzi Dien, Islamic law: from historical foundations to contemporary practice (Edinburgh University Press 2004), at 89. 
protect Islam and achieve the military victory over the Other who threatened the Islamic religion. ${ }^{101}$ Also, the destruction of property is permissible if it could not be avoided in the conduct of the hostilities. ${ }^{102}$ Beyond the killing and destruction of the Other, throughout the history of Islam, Muslim fighters themselves have wilfully used their bodies as means/weapons of warfare and have killed themselves for God's cause. ${ }^{103}$ Islamic extremists, such as Hasan al-Banna, one of the founding fathers of the Muslim Brotherhood (al-Ikhwan al-Muslimun) in Egypt, glorified the death of suicidal terrorist action and allegedly found a legal justification within the Qur'anic text, ${ }^{104}$ such as:

Let those fight in the cause of Allah Who sell the life of this world for the hereafter. To him who fighteth in the cause of Allah,- - whether he is slain or gets victory—soon shall We give him a reward of great (value). (Q4:74)

Man thus becomes a weapon for the cause of God and should be awarded in heaven. It remains to be seen whether as a method of warfare under ILW, suicide missions are really permissible or treacherous as they would also violate the principle to distinguish civilian from combatant status and also goes against the general prohibition of suicide under Islamic law. In this regard, according to Munir, suicide bombers commit at least five crimes under Islamic law, namely, "killing civilians, mutilating their bodies, violating the trust of enemy soldiers and civilians, committing suicide and destroying civilian objects or properties". ${ }^{105}$ Indeed, the Qur'an adds that:

Whether open or secret; take not life, which Allah hath made sacred, except by way of justice and law: thus doth He command you, that ye may learn wisdom. (Q6:151)

\subsubsection{On Proportionality}

The higher objective of Islam is to command the good and to forbid the evil. Even within the context of warfare, the Qur'an desires to make peace above

101 Monte Palmer \& Princess Palmer, At the heart of terror: Islam, jihadists, and America's war on terrorism (Rowman \& Littlefield Publishers 2004), at 142.

102 Muhammad Zafrulla Khan, Islam: its meaning for modern man (Routledge \& Kegan Paul 1980), at 178 .

103 See Bernard K. Freamon, 'Martyrdom, suicide, and the Islamic law of war: a short legal history', (2003-2004) 27 Fordham International Law Journal, 299.

104 Towqueer Alam Falahi, The Quranic concept of war and peace (Kanishka Publishers 2004), at 68 .

105 Muhammed Munir, 'Suicide attacks and Islamic law', (2008) 90 International Review of the Red Cross, 71, at 71 . 
killing and bloodshed. ${ }^{106}$ In view of persuading new (and old) followers to join the Islamic community (again), from the early Islamic conquests onwards, Islamic warfare necessarily had its limitation to achieve its religious cause, i.e. to protect the Islamic religion from aggression. Therefore, deliberate destruction and massacres were generally excluded ${ }^{107}$ as well as the extension of the conflict when peace could be concluded. In spite of the unavoidable calamities of warfare suffered by all parties to the conflict as witnessed for example by the extensive number of Arab casualties during the early Islamic age, ${ }^{108}$ the peaceful and egalitarian message as carried out by Islamic conquerors, in particular under the Ottomans, has helped in extending the abode of peace and in spreading the Islamic religion beyond its initial boundaries. ${ }^{109}$ During warfare, it is believed that God is watching and approving His fighters' steadfastness to this higher objective of self-restraint and justice. ${ }^{110}$ Muslim fighters who on their own initiative have persevered in their just conduct towards their enemies will be rewarded by God. The same attitude is required in their reaction to the enemies' violation of their self-imposed natural law principles of protection; belligerent reprisals have to be proportionate to the crimes inflicted upon the Muslims. Muslim fighters are personally responsible for their actions and intentions before God. ${ }^{111}$ Only God can see whether their conduct has been righteous toward the enemies. This principle of proportionality is well reflected in the following Qur'anic provisions:

And if ye do catch them out, catch them out no worse than they catch you out: But if ye show patience, that is indeed the best (course) for those who are patient. (Q16:126)

Help ye one another in righteousness and piety, but help ye not one another in sin and rancour: fear Allah. For Allah is strict in punishment. $(\mathrm{Q} 5: 2)$

106 Rudolph Peters, Jihad in medieval and modern Islam: the chapter on jihad from Averroes' legal handbook "Bidayat al-mudjtahid" and the treatise "Koran and fighting" by the late Shaykh al-Azhar Mahmud Shaltut (Brill 1977), at 27.

107 Hugh Kennedy, The great Arab conquests: how the spread of Islam changed the world we live in (Weidenfeld \& Nicolson 2007), at 372-73.

108 Michael Lecker, 'On the burial of martyrs in Islam', in Hiroyuki Yanagihashi (ed), The concept of territory in Islamic law and thought (Kegal Paul International 2000), at 37.

109 Dankwart A. Rustow, 'Political ends and military means in the late Ottoman and postOttoman Middle East', in Vernon John Parry \& Malcolm E. Yapp (eds), War, technology and society in the Middle East (Oxford University Press 1975), at 386-87.

110 Khan, Islam: its meaning for modern man, at 179.

111 John Kelsay, Arguing the just war in Islam (Harvard University Press 2007), at 193. 
Every soul will be (held) in pledge for its deeds. (Q74:38)

For Allah is with those who restrain themselves, and those who do good. (Q16:128)

Advocating human dignity during armed hostilities as part of adhering to this higher objective to command the good and to forbid the evil, has in reality not always been that successful. Again, the normative construction of the Other along different jurisdictional regimes has influenced the application of the principle of proportionality. Clearly, beyond the doctrinal and textual promises to respect the Other lies a more cruel reality where the interests to wage war against the enemies have determined, from the outset, the attitude towards the enemies of Islam. In this regard, invoking military necessity as a legal excuse can overcome the primary obligations to respect innocent life for the sake of defending the ummah. In Sunni Islam, such determination of public interest, i.e. maslaha, remains at the discretion of juristic and political authorities; in Shi'i Islam, similar recourse to the argument of preserving the Islamic state is usually raised by the political authority.12 The legal indeterminacy of the necessity and/or public interest is a powerful tool to divide and rule which at any time can be used by the leaders within the Islamic community to deny the protection which the sacred texts provide to all members of humanity who are involved in armed conflicts with the believers.

\subsection{Back to Tradition}

\subsubsection{Confronting the Evil}

Throughout the history of Islam, the identity politics, which divided the "Islamic" Self from its Other, have always been manipulated by many establishments whether they were of juristic, military, political, or religious nature. In order to divide and rule over their opponents and even their own subjects, these authorities became authoritarian in their reading of the authoritative sacred texts. They used their reason to extract the meaning of those texts in such a manner that the text became constructed according to their benefit; while the text only is supposed to have the sole authority given its Revelation

112 Sohrab Bedhad, 'Islam, revivalism and public policy', in Sohrab Behdad \& Farhad Nomani (eds), Islam and public policy (JAI Press 1997), at 14. 
by the God, who, to Muslims, is the only sovereign in this world. ${ }^{113}$ Again the tension between the rationalist and the traditionalists emerged in this extraction of the rules from the Qur'an and the Sunnah as respectively translated in the doctrine of acquisition and of creation. In sensu largo, the utilitarian attitude of the establishments to serve their own interests before those of the community and those of others confirms, somehow, their interpretation of the texts in order to realise their own understanding of justice; while according to the traditionalists such prerogatives only belong to God. ${ }^{114}$ Hence, in practice as understood from the dominant rationalist perspective, the whole process of establishing Islamic law, i.e. ijtihad, can merely be the approximation of the actual revealed laws. ${ }^{115}$ The authority attributed to the law as extracted by the jurists from the sacred texts not only sanctioned those texts, but transferred the original sovereignty which resides in God alone into the human world where the revealed law instead, as interpreted by the jurists, became representative of that sovereignty. Thus, it has been argued that the Islamic community has become a nomocracy. ${ }^{116}$ In this view, jurists only have intended to approximate the higher objective to command the good and to forbid the evil. But the jurist also introduced new legal concepts, such as the dar al-Islam and dar alharb, which allegedly were sanctioned by the scriptures. ${ }^{117}$ Their interpretation of the sacred instead of the texts themselves became authoritative and has, de facto, put the jurists at the source of the laws they have created. If in theory the jurists stand above the laws they have created, then, from an egalitarian perspective, they also lack the authority to impose them upon others. ${ }^{118}$

The juristic interpretations started to live their own reality as in their turn they would be reflective of the situation on the battlefield which has found its justification/legitimation in their divisive doctrines. Such hermeneutic rationalisations created a new reality alleged to be sanctioned by the sacred texts and were understood to be necessary to face the challenges the Islamic

113 Khaled Abou El Fadl, The authoritative and authoritarian in Islamic discourses: a contemporary study (Al-Saadawi Publications 2002), at 56.

114 Majid Khadduri, The Islamic conception of justice (Johns Hopkins University Press 1984), at 54-9.

115 Bernard G. Weiss, 'Interpretation in Islamic law: the theory of ijtihad', (1977-1978) 26 American Journal of Comparative Law, 199, at 205.

116 Wael B. Hallaq, '“Muslim rage” and Islamic law', (2003) 54 Hastings Law Journal, 1705, at 1707 .

117 Norman Calder, Studies in early Muslim jurisprudence (Clarendon Press 1993), at 218.

118 Ahmad Atif Ahmad, Structural interrelations of theory and practice in Islamic law: a study of six works of medieval Islamic jurisprudence (Brill 2006), at 14. 
empires met from within and outside their boundaries. ${ }^{119}$ In warfare, darura, i.e. military necessity, and maslaha, i.e. the public good, were examples of such seemingly objective concepts which could bypass the tolerant attitude towards the internal and external enemies of Islam and which could serve the particular subjective preferences of only a few. ${ }^{120}$ Also the methodologies by which the jurists linked the text with the context and vice versa have given them enormous power to create and change realities within and beyond the text. For example, istishab, is a method to rationalise the (non-)existence of certain rules which allows for, or prevents, new ones to be created. Such permissibility is central to Islamic law: everything is allowed unless forbidden. ${ }^{121}$ Clearly, reason can possibly justify and create any law unless already explicitly forbidden. Hence, the law and reason are closely connected. ${ }^{122}$

Within the Islamic legal sciences, the relative and limited power of rationality ${ }^{123}$ seems to be equated with the absolute truth it wants to extract. ${ }^{124}$ Because of its authoritativeness, the dangers of utilitarianism can lead to the realisation of interests of the "Islamic" Self alone at the expense of the other members of humanity. ${ }^{125}$ From the early beginnings of the history of Islam, the appeal to rationalise one's personal wishes through analogical reasoning was part of an open attitude stimulating the access to knowledge. ${ }^{126}$ Later onwards, however, when the compilation of the Sunnah came into existence, reference to scriptures somehow limited the unbound exercise of ijtihad.127 Although

119 Ebrahim Moosa, 'Languages of change in Islamic law: redefining death in modernity', in Ravindra S. Khare (ed), Perspectives on Islamic law, justice, and society (Rowman \& Littlefield 1999), at 163 .

120 M. Cherif Bassiouni \& Gamal M. Badr, 'The Sharia'h: sources, interpretation, and rulemaking', (2002) 1 UCLA Journal of Islamic and Near Eastern Law, 135, at 158.

121 Mohammad Hashim Kamali, Principles of Islamic jurisprudence (Islamic Texts Society 2003), at 395-96.

122 Abu al-Fazl Izzati, An introduction to Shi'i Islamic law and jurisprudence with an emphasis on the authority of human reason as a source of law according to Shi'i law (Ashraf Press 1976), at 15 .

123 Muhammad Mumtaz Ali, Islam and the Western philosophy of knowledge: reflections on some aspects (Pelanduk Publications 1994), at 89-90.

124 Noel James Coulson, Conflicts and tensions in Islamic jurisprudence (University of Chicago Press 1969), at 6.

125 Murtada Mutahhari, Understanding Islamic sciences: philosophy, theology, mysticism, morality, jurisprudence (ICAS Press 2002), at 198.

126 Faruqi al-Isma'il, 'Islam as culture and civilization', in Salem Azzam (ed), Islam and contemporary society (Longman 1982), at 150.

127 Ahmad Hasan, Analogical reasoning in Islamic jurisprudence: a study of the juridical principle of qiyas (Adam 1994), at 27. 
people make the law, the Qur'an remains the constitution. The function of the juristic authorities to elaborate on the law necessarily has transferred the sovereignty of the law upon them. They would represent the ijma, i.e. the will of the community. ${ }^{128}$ It is accepted that such contextualisation of Islamic law in its elaboration is useful to accommodate the revealed text to the changing circumstances; however, it can never be fully free from the selfish interests of those establishments who are giving their own interpretations. ${ }^{129}$ It remains difficult to entirely change this selfish human condition for the benefit of humanity as a whole. Though, the reality of warfare necessarily demonstrates such tension in the duality of human nature, namely to know one another, as indicates Q49:13, is a pedagogical task. ${ }^{130}$

Not only has the juristic division of the world into the abode of war and abode of peace been an example of denying the need for solidarity between all members of humanity, the practical violation of the principles of protection such as distinction and proportionality during armed hostilities is another illustration where identity politics have continued to have their effects within this legal fiction. Within this context of war, it would be justifiable that those principles could be set aside upon the basis of military necessity. The perceived irrational aggressiveness of the internal and external enemies of Islam ${ }^{131}$ can rationally necessitate, as a matter of self-defence, a response on behalf of the Muslims. If the enemy only understands a language of violence, then a likewise and reciprocal violent answer would be reasonable and hence legitimate. While this may conform with natural law, over-rationalising such violent Other justifies any legitimate action and this remains at the discretion of the authorities in place at a given moment in the history of Islam. ${ }^{132}$ In addition, being convinced of the superiority of the "Islamic" Self towards its inferior Other contributed to such worldview whose confines need to be protected at all (humanitarian) costs. As a self-fulfilling prophecy, the relationship between the practice and the doctrine can be established by the juristic authorities whose role was to reconcile both ends for the sake of justifying warfare against their enemies under the banner of implementing the divine commands to establish world peace. Within this juristic exercise, the intention/consciousness

\footnotetext{
128 Ahmad Hasan, The doctrine of ijma in Islam (Islamic Research Institute 1976), at 22.

129 Yusuf Qaradawi \& Al-Hadi A. Khalifa, Islamic law in the modern world (King Faisal Center for Research and Islamic Studies 2000), at 23.

130 Mohammed Arkoun, Islam: to reform or to subvert? (Saqi 2006), at 129.

131 Amyn B. Sajoo, Muslim ethics: emerging vistas (I.B. Tauris 2004), at 50.

132 Mohammed Arkoun, Pour une critique de la raison islamique (Maisonneuve et Larose 1984), at 79 .
} 
to divide the world in conflicting terms as opposed to the complementary ones of the Qur'an shows that the jurists had exclusivist agendas denying the real potential of pluralist coexistence from the outset. ${ }^{133}$ Or as put by Tibi in the following words:

In this sense, Muslims believe that expansion through war is not aggression but a fulfilment of the Qur'anic command to spread Islam as a way to peace. The resort to force to disseminate Islam is not war (harb), a word that is used only to describe the use of force by non-Muslims. Islamic wars are not hurub (the plural of harb) but rather futuhat, acts of "opening" the world to Islam and expressing Islamic jihad. ${ }^{34}$

\subsubsection{Fighting the Inner Jihad}

In spite of the natural differences between the members of humanity, the challenge of humanity is to embrace this richness and diversity. ${ }^{135}$ What distinguishes Islam from other religions or even secularist worldviews, is the belief that God is the Creator of the universe and that His creation serves to experience the diversity as a blessing from Him. Therefore, in their relationship with all these other peoples, Muslims would see this interconnectedness of all human beings as well as their inherent solidarity between their spirits. Given this pluralistic world, some members of humanity do not believe in this blessing and rather resist it. This could lead to conflicts between Muslims and non-Muslims and also between Muslims themselves when they differ upon the path to be followed within their own belief. The legal fictions have only contributed to this tension and denied the complementarity of the creation to flourish in all its diversity. This conflict is and has been rather exploited for personal ends which violently destroys the community of humanity. In this respect, according to Nasr,

Islam, in controlling the use of force in the direction of creating equilibrium and harmony, limits it and opposes violence as aggression to the rights of both God and His creatures as defined by the divine Law. The goal of Islam is the attainment of peace, but this peace can only be experienced through ourselves and leads to living in the world in accordance with the dicta of the Sharia. Islam seeks to enable man to live according

\footnotetext{
133 Ayoub, at 220-22.

134 Tibi, 'War and peace in Islam', in, at 328.

135 Nathan C. Funk \& Abdul Aziz Said, Islam and peacemaking in the Middle East (Lynne Rienner Publishers 2009), at 218.
} 
to his theomorphic nature and not to violate that nature. Islam condones the use of force only to the extent of opposing that centripetal tendency which turns man against what he is in his inner reality. The use of force can only be condoned in the sense of undoing the violation of our own nature and the chaos which has resulted from the loss of equilibrium. But such a use of force is not in reality violence as usually understood. It is the exertion of human will and effort in the direction of conforming to the Will of God and in surrendering the human will to the divine Will. From this surrender (taslim) comes peace (salam), hence Islam, and only through this Islam can the violence inbred within the nature of fallen man be controlled and the beast within subdued so that man lives at peace with himself and the world because he lives at peace with God. ${ }^{136}$

Thus, God has mandated the ummah to be tolerant vis-à-vis and live in solidary with the other members of humanity. ${ }^{137}$ Such communitarian and naturalist approach requires an individual and spiritual effort, i.e. an inner jihad to open the "Islamic" Self up to its Other; ${ }^{138}$ namely to witness the diversity around oneself and to realise that one is part of this creation blessed with this diversity to know one another better through it. Such peaceful mindset starts with the Self first which accepts the roots of its creation, i.e. God. It has to submit to His commands to do good and to forbid the evil. It is the Qur'an which is the link between the divine and the human ${ }^{139}$ and which convinces Muslims of the unity between God and them. This harmonious complementarity of the creation is another feature of the unity emanating from God. ${ }^{140}$ The conscience which unites God with human beings functions as spiritual control on humanity's actions in its relations with Others, namely to treat them justly. ${ }^{141}$ Once God has breathed His spirit into Adam, ${ }^{142}$ i.e. the father of the human species, this spiritual conscience has its purpose to be fulfilled in the material world

136 Nasr, in, at 276 .

137 Abou El Fadl, The great theft: wrestling Islam from the extremists, at 208; Ahmet Alibasic, 'The place for others in Islam', (2007) 3 Comparative Islamic Studies 98, at 101.

138 John L. Esposito, 'Struggle in Islam', in Joshua Cohen \& Ian Lague (eds), The place of tolerance in Islam (Beacon Press 2002), at 76.

139 Ziauddin Sardar \& Merryl Wyn Davies, Distorted imagination: lessons from the Rushdie affair (London 1990), at 88.

140 Boisard, at 84.

141 Afif Abdulfattah Tabbarah, The spirit of Islam: an interpretive survey of the foundations, graces and teachings of Islam as seen in the light of science and philosophy (Abdel-Hafiz Bsat 1978), at 199 and 353 .

142 See Q15:29. 
where human beings live together. ${ }^{143}$ According to Christmann, this "'spirit of God' (memory) enabled nations to write their history self-reflectively and use historiography to enhance humankind's historical consciousness. By giving human beings knowledge and legislation, Allah initiated a qualitative jump in history: creatures turned into human beings through the acquisition of God's spirit."144

Such internal struggle to liberate one's heart from the material desires in the human world is a tremendous task and responsibility towards God and His creation. ${ }^{145}$ Directing this personal trial toward the oneness of God might link the human experience again with the love for God and consequently also for other human beings which are part of His creation. ${ }^{146}$ The search for internal peace with oneself and externally with others goes hand in hand with a lot of tensions which are complementary to this whole process of inward seeking. God shall reward those who have made the effort to find the right balance when meeting the internal and external challenges of human existence. But, as human history has shown, this internal tension to feel good with oneself and in its relationships with others has not always been that successful. Through their description of the world in conflicting terms, some Islamic jurists and theologians have somehow broken the potential solidarity between human beings. The consecutive disruption of this horizontal transcendentalism among human beings gave more authority to the jurists-theologians as they profiled themselves as the sole interlocutors between God and the believers. Moreover, their interpretation of the Qur'an is accompanied with an exclusivist rhetoric which blurs the reality of this unity of the creation. The required obedience to their rationalisation of the divine text is confused with the authority given to the Qur'an itself which constitutes the direct link between the divine and the human. Hence, the need to restore both the vertical and horizontal direct conscience/link between God and human beings respectively and among human beings themselves; so they are able to follow the righteous path/truth again, i.e. the divine will to learn from the diversity which is at the heart of human-

\footnotetext{
143 Abdur Razzaque, Prayer: for progress (Sh. Muhammad Ashraf 1967), at 48-9.

144 Andreas Christmann (ed), The Qur'an, morality and critical reason: the essential Muhammad Shahrur (Brill 2009), at 165.

145 Tariq Ramadan, Western Muslims and the future of Islam (Oxford University Press 2004), at 120.

146 Tariq Ramadan, Islam, the West and the challenges of modernity (Islamic Foundation 2001), at 61-2.
} 
ity's existence. ${ }^{147}$ The Golden Rule, according to Schweiker, is also another "religious expression to the imperative of responsibility, just as the symbols of creation signal the complexity of goods that constitute the moral space of life". 148

And among His Signs is the creation of the heavens and the earth, and the variations in your languages and your colours: verily in that are Signs for those who know. $\left(\mathrm{Q}_{30}: 22\right)$

Having found inner peace, human beings are able to live in peace with the unity of creation and the other members of humanity. ${ }^{149}$ The Qur'an teaches about the unity in diversity and not about the division of the world in artificial abodes of peace and war. ${ }^{150}$ Accepting the membership to this spiritual and material unity does not entail to give up the existence of material diversity. However, the effort is required to give up at least those selfish attributes which prevent to find the right balance to accept oneself within the greater whole of the creation. In fact, God has bestowed the creation with a natural equilibrium which human beings simply have to live up to again and have to avoid the domination of the personal preferences above the communitarian ones from which all human beings spiritually and materially benefit. ${ }^{151}$ Only such purified heart can witness the unity of God as lodged in His creation. ${ }^{152}$ In this respect, not only reason could convince humanity of the unity in diversity having a divine source, but intuition as followed by the heart, as observed by Rahman, "establishes the unity of the self as an abiding reality in the midst of multiplicity". ${ }^{153}$ Evidently, as the Qur'an realistically reveals, there will always

147 Mohammed Arkoun, Essais sur la pensée islamique (Maisonneuve et Larose 1973), at 188-91.

148 William Schweiker, Theological ethics and global dynamics: in the time of many worlds (Blackwell 2004), at 213.

149 Jacques Berque, L’islam au temps du monde (Sindbad 1984), at 254.

150 Israfil Balci, 'An Islamic approach toward international peace', in J. Dudley Woodberry, Osman Zümrüt \& Mustafa Köylü (eds), Muslim and Christian reflections on peace: divine and human dimensions (University Press of America 2005), at 120.

$15^{1}$ Muhammad Qutb, 'What Islam can give to humanity today', in Altaf Gauhar \& Islamic Council of Europe (eds), The challenge of Islam (Islamic Council of Europe 1978), at 319-20.

152 'Abdul-Qadir al-jilani \& Shaikh Tosun Bayrak al-Jerrahi al-Halveti, The secret of secrets (Islamic Texts Society 1992), at 56 and 76 .

153 Syedur Rahman, An introduction to Islamic culture and philosophy (Mullick Brothers 1963), at 149 . 
be a world of belief and disbelief that is part of His creation and that have to live together peacefully side by side:

To each among you have we prescribed a law and an open way. If Allah had so willed, He would have made you a single people, but (His plan is) to test you in what He hath given you: so strive as in a race in all virtues. The goal of you all is to Allah. It is He that will show you the truth of the matters in which ye dispute. (Q5:48)

If thy Lord had so willed, He could have made mankind one people: but they will not cease to dispute. Except those on whom thy Lord hath bestowed His Mercy: and for this did He create them: and the Word of thy Lord shall be fulfilled: "I will fill Hell with jinns and men all together." (Q11:118-119)

\subsubsection{Respecting God's Creation}

Understandably, the Revelation reflects the dichotomy between the world of belief and disbelief but not necessarily in conflicting terms. The creation reflects such duality which is also found in human nature. In this respect, the tension between the sovereign Self and the community on the level of the individual is also taking place on the global level between the believers and non-believers. As with the inner spiritual jihad, such tension is not supposed to be settled by violence but by transcending selfishness and aligning it with the communitarian aspects of life. A freed ego necessarily unfolds creativity to peacefully accommodate the interests of the Self with those of the Others. ${ }^{154}$ Whereas, the external and internal jihad against the so-called enemies of Islam, is settled through warfare. If humanity finds its inner peace, embraces the love of God and shares this love with all other members of humanity, then war will no longer be a means to achieve a world of inner and external peace. In this respect, violence becomes meaningless as it destroys the peace people have found in themselves and through each other as God has endowed them with such capability to find this peace both internally and externally. Persevering in these spiritual efforts can lead to positive results in the material world. Nonetheless, the Qur'an is aware of the duality to do good and bad things but urges humanity to develop itself for the good by following the path of God:

And those who strive in Our (cause), -We will certainly guide them to our Paths: for verily Allah is with those who do right. (Q29:69)

154 Allama Muhammad Iqbal, The reconstruction of religious thought in Islam (Sh. Muhammad Ashraf 1968), at 123. 
Repel evil with that which is best: We are well acquainted with the things they say. (Q23:96)

Fulfilling God's promise, i.e. the text/Revelation, within the universe, i.e. context, should not be reconciled through violence/jihad even though violence has always been part of human history until now. ${ }^{155}$ War would be a necessary evil as long as people are not convinced of the unity of existence created by God. ${ }^{156}$ The struggle to balance between the two complementary ends of the duality of human nature, i.e. to do good and evil, and the world, i.e. of belief and disbelief, have to be accompanied with political and social action instead. ${ }^{157}$ However, this struggle has been led by those authorities who found more benefits to portray the world in unbridgeable conflicting terms which could only be settled through violence with their promise that at the end of time peace would be found. Such division in order to rule has put the survival of the entire human species at stake for the benefit of those in power. Juristic authorities in particular have blurred the line between the Revelation and their human elucidations of the divine laws. ${ }^{158}$ As self-proclaimed guardians of the sacred texts, ${ }^{159}$ the jurists' authority on the legal traditions of warfare could not be challenged and was materialised in ijma, i.e. the will of Islamic community. Of course, as a community, the Muslims, throughout their history, have been the object of aggression. This historical context necessarily justified such a juristic elaboration of the divine rules which, however, went beyond the distinction of a complementary world of belief and disbelief as revealed by the Qur'an. Their legal fictions of a conflicting world of peace and of war did not bring justice to the revealed text. Despite their external facade to provide the ummah with such legal and political tools to defend itself against the aggressors, the authorities' intentions rather reveal a strategy to divide and rule through this permanent conflict. According to Esack, such exegetical and linguistic casuistry compels "inclusivist texts to produce exclusivist meanings". ${ }^{160}$

Those rationalisations of the Islamic jurisprudence only focus on the horizontal and external relationship among the members of humanity and not

155 Fazl-I-Ahmad Kuraishi, Islam: the religion of humanity (Kitab Manzil 1956), at 309.

156 Clement Huart, 'The law of war', in Andrew G. Bostom (ed), The legacy of jihad: Islamic holy war and the fate of non-Muslims (Prometheus Books 2005), at 284.

157 Mohammed Arkoun, Rethinking Islam: common questions, uncommon answers (Westview Press 1994), at 13.

158 John L. Esposito, Islam: the straight path (Oxford University Press 2005), at 227.

159 Daniel W. Brown, Rethinking tradition in modern Islamic thought (Cambridge University Press 1996), at 133 .

16o Farid Esack, Qur'an, liberation and pluralism: an Islamic perspective of interreligious solidarity against oppression (Oneworld 1997), at 147. 
on the vertical and internal relationship between human beings and God. ${ }^{161}$ Instead, the jurists' interpretation of the divine law stands between the divine law and its application by the believers and prevents believers to have direct access to the truth and justice which the Qur'an has revealed to this world. The jurists' introduction of legal fictions dividing the world in conflicting terms, as influenced by the historical narrative on the "Islamic" Self and its Other, has distorted the true meaning of the Qur'an, as revealed at this particular moment in Arab history. ${ }^{162}$ And reason portrayed as the ultimate means to access the truth of the divine commands would attribute the sole authority of jurists to actually do so. Nevertheless, all human beings can also access God not through reason only but through the heart as well. Therefore, the jurists' intermediary between God and the believers only has its anticipated effects within a paradigm which puts reason central in the endeavours to access the sacred texts and where historical data confirm the lived realities of their legal fictions. While, from the "life paradigm" which puts human conscience central in these efforts to witness the love of God in and for His creation, the relationship between God and the believers enables to transcend the artificial divisions which humanity, as part of its human nature, has introduced upon itself in order to divide and rule.

Going beyond the legal discourse as dominated by reason and juristic authorities is essential to give voice again to the human conscience, both vertically and horizontally, which is already present but which is deafened by such legal formalism. Such solidarity among all human beings can awaken humanity of the risks it has endured during its human history where it continuously has put the survival of its very kind at stake. The life bestowed by God upon His creation is a blessing. Therefore, the higher objective to command the good and to forbid the evil has to bring together human beings as true agents of their existence in this world for which they remain accountable toward their others in the here and toward God in the hereafter. Warfare and destruction, though they have been part of humanity's history, no longer have any place in the paradise on earth which God has created for the benefit of all humanity. Though God acknowledges the duality of human nature in its last Revelation, i.e. to make peace and to wage war, its last Revelation was also a reminder of the potential He has put in His creation and in human beings to find the right

161 Baber Johansen, Contingency in a sacred law: legal and ethical norms in the Muslim fiqh (Brill 1999), at 24.

162 Allahbukhsh K. Brohi, 'Islam: its political and legal principles: a proglomena to the theory and practice of politics and law', in Salem Azzam (ed), Islam and contemporary society (Longman 1982), at 97 . 
balance and to act with justice between the interests of the Self and the Other so they can find inner peace with the Self and the Other. The fruits of this potential lie in the human conscience to find Him and all other human beings through Him; and humanity is the bearer of those fruits. Such conscience ultimately bounds all human beings in their shared material existence and most importantly in the spiritual world where their spirit originates. Or as Ramadan concludes:

This initial positive outlook, associated with the invitation to human conscience to remember and be thankful, is of foremost importance. It affects all the areas of human knowledge about the created Universe: a Universe that is both a gift and a "sign" fraught with meaning and its Creator. ${ }^{163}[\ldots]$ Humankind must, through the ethics of their actions in the world, try to remain faithful to what they have received in the very nature of their being in the world. One should therefore act faithfully and not forget to be thankful. ${ }^{164}$

\section{$5 \cdot 5 \quad$ Conclusion}

This chapter has tried to establish that the identities on the "Islamic" Self and its Other have informed the creation and application of the legal fictions which jurists have constructed in order to justify and legitimatise the use of violence against the internal and external enemies of Islam. The creation of the jurisdictional regimes regulating warfare within the abode of peace, i.e. dar al-Islam, and the abode of war, i.e. dar al-harb, did provide for the universal principles of protection, i.e. those of distinction and proportionality. As almost a matter of natural law these communitarian principles had to be safeguarded against the calamities of warfare. However, these same principles are set aside by the sovereignty argument of military necessity only in those situations where the enemy has violated one of those principles first. As a response to that, Muslim fighters can retaliate but only likewise without transgressing in their actions.

Within this legal framework, jurists have attributed themselves the authority to establish the laws of war and indirectly affect the conduct of hostilities. Such power enabled them and the other interest groups in Islamic societies to divide and rule over their subjects and deny them the access to challenge

163 Tariq Ramadan, Radical reform. Islamic ethics and liberation (Oxford University Press 2009), at 104.

164 Id., at 90. 
their sophisticated modes of reasoning. They have put themselves between the revealed divine texts and the Muslim populace. By inserting conflicting divisions within the interpretation of Islamic law, the jurists, albeit unintentionally, appear to have distorted the true meaning of the Qur'an which describes the world in complementary terms. The interconnectedness of all human beings necessarily was blurred through those legal fictions and humanity was made a passive receiver of them and their lived realities. Believing again in the unity of the world and its diversity as created by God is a possible avenue to see this complementarity of human existence. As freed agents, human beings can embrace God's blessing and life again for the sake of the survival of the entire species through a more naturalist reading and application of ILW. 